\title{
ПОТЕНЦИЈАЛИ РАЗВОЈА КУЛТУРНОГ ТУРИЗМА НА ПРОСТОРУ ТОПЛИЧКОГ ОКРУГА
}

Горан Перић ${ }^{1}$, Александра Јевтовић, Марко Гашић

\begin{abstract}
Сажетак
Топлички округ се налази на југу Републике Србије и поседује бројне природне и антропогене туристичке вредности, које омогућавају креирање, промоцију и пласман туристичких атрактивности не само на домаћем, већ и на међународном туристичком тржишту. Према томе, циљ овог рада представља утврђивање потенцијала за развој културног туризма у Топличком округу који обухвата четири општине: Прокупље, Куршумлија, Блаце и Житорађа. Идентификоване су културне вредности на територији целог округа које могу бити туристички валоризоване и утврђено је да постоји солидна материјална база за развој различитих облика туризма. Наглашено је да будући развој туризма мора бити сагласан са концептом одрживог развоја, као и да је неопходно израдити стратегију развоја туризма. Та стратегија би могла бити појединачна по општинама или јединствена на нивоу Топличког округа, која чини основу планског развоја туризма. На крају, наведено је да не постоји могућност развоја културног туризма као засебног облика, већ да је неопходно културне вредности Топличког округа инкорпорирати у већ добро профилисан бањски туристички производ, а у складу са захтевима савременог туристе.
\end{abstract}

Кључне речи: културни туризам, културне вредности, материјална база, Топлички округ.

Академија струковних студија Јужна Србија, Одсек за пословне студије Блаце e-mail: goran.peric@vpskp.edu.rs 


\title{
DEVELOPMENT POTENTIALS OF CULTURAL TOURISM IN THE AREA OF TOPLICA DISTRICT
}

\begin{abstract}
Toplica district is located in the south of the Republic of Serbia and has numerous natural and anthropogenic tourist values which enable the creation, promotion and placement of tourist attractions not only on the domestic but also on the international tourist market. Therefore, the aim of this paper is to determine the development potentials of cultural tourism in the Toplica district, which includes four municipalities: Prokuplje, Kuršumlija, Blace and Žitorađa. Cultural values which can be valorized for tourism have been identified on on the territory of the entire district and it has been determined that there is a solid material base for the development of various forms of tourism. It was emphasized that the future development of tourism must be consistent with the concept of sustainable development and that it is necessary to develop a tourism development strategy. That strategy might be individual by municipality or uniqe at the level of Toplica district, which forms the basis of planned tourism development. Eventually, it was stated that there is no possibility of developing cultural tourism as a separate form but that it is necessary to incorporate the cultural values of the Toplica district into an already well-profiled spa tourist product and according to requirements of modern tourists.
\end{abstract}

Key Words: cultural tourism, cultural values, material base, Toplica district.

\section{Увод}

Република Србија се у прошлости суочавала са бројним проблемима који су између осталог утицали и на развој туризма. Велике промене које су се догодиле на међународном туристичком тржишту заобишле су Републику Србију, јер она није прилагодила своју туристичку понуду савременим трендовима, те је нужно драматично побољшање конкурентности туристичке понуде, а у складу са жељеним позиционирањем на туристичком тржишту (Ракић и др., 2014). Достигнути ниво развоја туризма у Републици Србији, упркос постојању квалитетне и разнолике ресурсне основе, по свим битним показатељима знатно заостаје у односу на ресурсне и тржишне могућности његовог развоја (Čerović i dr., 2015). Слична ситуација је и са културним туризмом, који се још увек не издваја као јасно профилисан вид туризма јер 
културне вредности нису претворене у осмишљене туристичке производе, нити се у довољној мери културне вредности интегришу у већ профилисане туристичке производе.

Циљ овог рада је утврђивање потенцијала за развој културног туризма у Топличком округу којег чине општине Прокупље, Куршумлија, Блаце и Житорађа. Реч је о просторној целини са значајним туристичким потенцијалима који су данас само делимично искоришћени за развој појединих облика туризма.

Топлички округ обилује мноштвом туристичких потенцијала, који омогућавају креирање, промоцију и пласман туристичких производа не само на домаћем, већ и на међународном туристичком тржишту. Околне планине, природни феномен Ђавоља варош, близина Поповачког језера, археолошки локалитети из праисторије и римског периода, манастири који потичу из средњег века, из периода турске владавине и новије историје, Пролом, Луковска и Куршумлијска Бања чине ово подручје веома примамљивом туристичком дестинацијом. Нажалост, ови потенцијали су због недовољно изграђене саобраћајне и туристичке инфраструктуре и слабе промоције туристичких производа веома мало искоришћени, на шта указује врло мали број туриста који посећују Топлички округ, изузев Пролом и Луковске Бање.

Учешће културног туризма у укупним туристичким кретањима процењено је на око 37\% свих међународних путовања (Hrbovski - Tomić, 2008). Културни туризам у Републици Србији се још увек не издваја као јасно профилисан вид туризма јер културне вредности нису претворене у осмишљене туристичке прозиводе и још увек чине само потенцијале на којима може да се развија културни туризам (Jovanović, 2015). Иста ситуација је и са културним туризмом у Топличком округу, с тим што бање у оквиру развијеног бањског туристичког производа покушавају да интегришу културна добра у своју туристичку понуду, што свакако доприноси дужини боравка у Пролом и Луковској Бањи.

\section{1. ПРЕГЛЕД ЛИТЕРАТУРЕ}

Туризам и културу много тога повезује и они синергијом граде културни туризам. Велики број туриста се одлучује за путовање управо мотивисани жељом да упознају културно и историјско наслеђе једног места, региона или земље. Постоје бројне дефиниције културног туризма, али није могуће одабрати једну, с обзиром на то да је реч о кровном термину који под своје окриље прихвата историјске, уметничке, етничке, верске, спортско- 
рекреативне и остале селективне облике туризма (Sančanin i dr., 2019). Једну од најцитиранијих дефиниција дао je Richards (1996) према којем „културни туризам означава кретање људи које је проузроковано културним атракцијама изван њиховог места сталног боравка, са намером скупљања нових информација и искустава, како би задовољили своје културне потребе“. Светска туристичка организација дефинише културни туризам као „путовање особа искључиво ради задовољења културних потреба, као што су студијска путовања, посета фестивала, концерата и других догађаја, обилазак споменика културе, путовање ради проучавања фолклора или религијска путовања" (Исаковић, 2016). Међутим, након одређеног времена, Светска туристичка организација на 22. седници Генералне скупштине усваја нову оперативну дефиницију, према којој је „културни туризам врста туристичке активности у којој је основна мотивација посетиоца да у туристичкој дестинацији научи, открије, искуси и конзумира опипљиве и нематеријалне културне атракције/производе на туристичкој дестинацији" (UNWTO, 2019 цитирано у Sančanin i dr., 2019). Са друге стране,Ђукић Дојчиновић (2005) истиче да се културни туризам дефинише са неколико различитих аспеката:

- са економског аспекта, културни туризам подразумева присуство „производа“" културе на туристичком тржишту са уметничким вредностима које доносе приход, а пре свега, општу корист;

- са туризмолошког аспекта, дефинише се као кретање особа мотивисано културним потребама и односи се на места која нису туристички развијена и културолошки довољно афирмисана;

- са културолошког становишта, то је сав онај скривени културни потенцијал који један град или регион има, и који доноси културни и уметнички доживљај локалној публици и посетиоцима;

- са едукативног становишта, то је туристичко путовање са жељом да се истражује, упозна и научи о националним и локалним културним вредностима средине која се посећује;

- са организационог становишта, то је интерсекторско повезивање туризма и културе, као две комплементарне гране које се удружују у креирању заједничког туристичког производа.

На глобалном туристичком тржишту, културни туризам као селективни облик туристичких кретања, последњих година бележи изузетан раст (Милошевић, 2014). У наставку биће дат преглед врста туризма и припадајући туристички производи и активности.

Табела 1: Врсте културног туризма 


\begin{tabular}{|c|c|}
\hline Врсте културног туризма & Туристички производи и активности \\
\hline $\begin{array}{l}\text { Туризам орјентисан на } \\
\text { културну баштину }\end{array}$ & $\begin{array}{l}\text { Природно и културно наслеђе (повезано са еко } \\
\text { туризмом) } \\
\text { Материјални - грађевине, архитектонске локације, } \\
\text { локалитети светске баштине, историјски споменици } \\
\text { Нематеријални - књижевност, уметност, фолклор } \\
\text { Културна баштина - музеји, библиотеке, позоришта, } \\
\text { историјски локалитети }\end{array}$ \\
\hline Културно - тематске руте & $\begin{array}{l}\text { Широк спректар тема и типова рута - духовне, } \\
\text { индустријске, уметничке, гастрономске, } \\
\text { архитектонске итд. }\end{array}$ \\
\hline Културни - градски туризам & $\begin{array}{l}\text { Градски туризам - разгледање } \\
\text { Културне престонице Европе } \\
\text { Креативни градови }\end{array}$ \\
\hline Етно туризам & $\begin{array}{l}\text { Традиција локалних култура } \\
\text { Национална и етничка разноликост }\end{array}$ \\
\hline Манифестациони туризам & $\begin{array}{l}\text { Културни фестивали и догађаји - музички фестивали } \\
\text { и догађаји, фестивали и уметничка дешавања }\end{array}$ \\
\hline Верски туризам & $\begin{array}{l}\text { Посећивање сакралних локација мотивисани } \\
\text { верским разлозима } \\
\text { Посећивање сакралних локација без верске } \\
\text { мотивисаности (посећивање верских споменика због } \\
\text { културних вредности) } \\
\text { Ходочашће }\end{array}$ \\
\hline Креативни туризам & $\begin{array}{l}\text { Традиционалне културне и уметничке активности } \\
\text { - мултимедијални догађаји, визуелне уметности, } \\
\text { филмски фестивали, ликовне колоније, штампа, } \\
\text { занатство и сл. }\end{array}$ \\
\hline
\end{tabular}

Извор: Csapo, J. (2012). The role and importance of cultural tourism in modern tourism industry. In Strategies for tourism industry-micro and macro perspectives. InTech.

Главни, односно директно повезани облици туризма са културним туризмом јесу сеоски туризам (традиција, стил живота, локална гастрономија), вински туризам, као и етно туризам (Csapo, 2012).

Основа развоја културног туризма су културна добра материјалног и нематеријалног карактера, те је њихово очување важно у смислу одржавања друштвене и културне вредности (Petković, 2019). Данас практично у свим градским или сеоским срединама постоји велики број локалитета културно-историјског наслеђа, због којих одређена места постају атрактивне дестинације и привлаче бројне посетиоце (Jovanović-Tončev \& Podovac, 
2014). Културне вредности материјалног и нематеријалног карактера обогаћују основни туристички производ, те је због тога важан интегративни приступ који побољшава имиџ дестинације, повећава потрошњу, дужину боравка туриста и њихово задовољство (Sančanin, 2019; Jovanović-Tončev \& Podovac, 2014). Производи културе нису саме грађевине или предмети из прошлости већ је важан начин њихове интерпретације (Jovanović-Tončev \& Podovac, 2014), односно морају бити за посетиоце извор емоција, пружити им одређени доживљај (Vrtiprah, 2006).

\section{2. МАТЕРИЈАЛНА БАЗА ЗА РАЗВОЈ ТУРИЗМА И КУЛТУРНЕ ВРЕДНОСТИ ТОПЛИЧКОГ ОКРУГА}

Материјална база - Територија Топличког округа се налази на југу Републике Србије и обухвата географску и историјску област, познату као Топлица, која се налази у сливовима реке Топлице и Косанице. Туристичко - географски положај Топличког округа представља битну компоненту туристичке валоризације регије у целини, а самим тим и њених туристичких ресурса различите структуре, просторне величине и организације (Гашић \& Ивановић, 2015). Последњих неколико година, захваљујући добром геотуристичком положају у односу на остале важније путне правце, доброј саобраћајној повезаности и растућој популарности бањског туризма, све је више туриста из већих центара Србије, посебно из Београда и Новог Сада (Бојовић, 2012).

Један од најважнијих фактора развоја туризма су и рецептивни фактори. У оквиру њих, значајно место заузима хотелијерство. Посматрано кроз историју, смештајни капацитети се везују за појавне облике туризма. Хотелијерство као развојна компонента туризма представља препознатљив елемент туристичког простора (Bakić, 2005). У Топличком округу постоји солидна материјална база за развој различитих облика туризма. Развија се саобраћајна инфраструктура, а посебно је важна најава изградње аутопута Ниш - Приштина. Такође, последњих година је приметан развој у изградњи и модернизацији постојећих угоститељских капацитета. Наиме, потпуно је обновљен хотел „Наmmeum“ у Прокупљу који је категоризован са четири звездице. Значајну улогу у модернизацији постојећих, али и развоју и изградњи нових туристичких и смештајних капацитета целог Топличког округа има акционарско друштво “Планинка” из Куршумлије (Gašić i dr., 2015). Од свог оснивања, ово предузеће је континуирано доприносило развоју туризма, а данас се сматра главним носиоцем туристичког развоја Топличког 
округа (Jevtović, 2020). Посено треба истаћи његовуулогуу промоцији туризма и повећању економских ефеката од ове делатности. Предузеће „Планинка“ из Куршумлије ушло је у значајне инвестиционе подухвате који се огледају у модернизацији постојећих и изградњи нових хотелских капацитета. Наиме, Луковска бања ће следеће године добити још један хотел капацитета 230 лежаја, који ће бити категоризован са четири звездице, а укупна вредност инвестиције премашиће 5 милиона евра (Turistički svet, 2017). Такође, исто предузеће купило је хотел „Жубор“ у Куршумлијској бањи, у који ће бити уложено преко 12 милиона евра, а први гости се очекују крајем следеће године (РТС, 2020). У следећој табели биће дат приказ смештајних капацитета у Топличком округу.

Табела 2: Смештајни капацитети у Топличком округу

\begin{tabular}{|c|c|c|}
\hline Смештајни објекти у Топличком округу & Број лежајева & Категорија \\
\hline Хотел “Hammeum” Прокупље & 80 & $* * * *$ \\
\hline Хотел “Радан” Пролом бања & 426 & $* * *$ \\
\hline Хотел “Гаретов конак” Пролом бања & 84 & - \\
\hline Хотел “Копаоник” Луковска бања & 120 & - \\
\hline Хотел “Јелак" Луковска бања & 208 & $* * *$ \\
\hline Хотел “Топлица” Прокупље & 60 & - \\
\hline Хотел “Жубор” Куршумлијска бања & 240 & - \\
\hline Хостел “Франица” Куршумлија & 32 & - \\
\hline Хотел“IN” Блаце & 100 & - \\
\hline Мотел “Рударе” Рударе & 60 & ** \\
\hline Укупан број лежајева & 1410 & - \\
\hline
\end{tabular}

Извор: Модификовано према Gašić, M., Ivanović, V., \&Perić, G. (2015). Materijalna baza razvoja turizma na prostoru Topličkog okruga. U: Synthesis 2015 - International Scientific Conference of IT and Business-Related Research. (str. 494-498). Univerzitet Singidunum.

Број смештајних капацитета приказаних у претходној табели треба узети условно, имајући у виду да одређени број капацитета није у функцији (хотели „Жубор“ и „IN“, као и мотел „Рударе“). Међутим, имајући у виду инвестиције које су у току, следеће године ће број смештајних капацитета свакако бити већи за преко 200 лежајева. Постојећа, недовољно искоришћена туристичка 
инфра и супраструктура, кадрови, локалне туристичке организације и посредничке туристичке агенције, као и добра саобраћајна повезаност представљају солидну материјалну основу за развој различитих облика туризма на простору Топличког округа.

Туристички промет - Савремени развој туризма у Топличком округу почиње изградњом модерних хотелско-угоститељских капацитета и реконструкцијом старих објеката (Гашић, 2012). Туризам у Топличком округу почео је да се развија шездесетих година прошлог века и имао је константан раст туристичког промета, све до 1990 године, када почиње рапидно да се смањује због политичко - економске ситуације (Gašići dr., 2015). Након 2000. године десиле су се бројне промене, затворени су одређени смештајни капацитети, попут хотела у Прокупљу и Куршумлијској бањи, што се одразило и на драстичан пад туристичког промета. Број туриста који су посетили Топлички округ у периоду од 2010. до 2019. године, кретао се од 23.337 до 31.620 хиљада у 2018. години када је остварен највећи број долазака, док се у истом периоду број ноћења кретао између 118.841 и 181.077 хиљада, што се може уочити из табеле која следи.

Табела 3: Кретање броја туриста и ноћења у Топличком округу у периоду од 2010. до 2019. године

\begin{tabular}{|c|c|c|c|c|c|c|}
\hline \multirow{2}{*}{ Година } & \multicolumn{3}{|c|}{ Доласци } & \multicolumn{3}{c|}{ Ноћења } \\
\cline { 2 - 7 } & Укупно & Домаћи & Страни & Укупно & Домаћи & Страни \\
\hline 2010. & 23377 & 21742 & 1635 & 118841 & 114698 & 4143 \\
\hline 2011. & 28547 & 25206 & 3341 & 141891 & 134461 & 7430 \\
\hline 2012. & 27887 & 24458 & 3429 & 151360 & 142221 & 9139 \\
\hline 2013. & 24208 & 21722 & 2486 & 133303 & 124998 & 8305 \\
\hline 2014. & 22990 & 20023 & 2967 & 135179 & 124855 & 10324 \\
\hline 2015. & 27170 & 22535 & 4635 & 157013 & 142733 & 14280 \\
\hline 2016. & 27856 & 24152 & 3704 & 166259 & 153502 & 12757 \\
\hline 2017. & 29950 & 24948 & 5002 & 176812 & 160367 & 16445 \\
\hline 2018. & 31620 & 26279 & 5341 & 177368 & 159880 & 17488 \\
\hline 2019. & 31516 & 26083 & 5433 & 181077 & 162947 & 18130 \\
\hline
\end{tabular}

Извор: Републички завод за статистику. (2020). Доласци и ноћењ а туриста по регионима и областима - годишњи подаци.

На основу података приказаних у претходној табели може се уочити да 
број долазака осцилира по годинама, док број ноћења показује константан раст. Такође, треба напоменути да општина Куршумлија са својим бањама (Пролом и Луковска бања) учествује са преко 95\% у укупном туристичком промету на нивоу Топличког округа.

Топлички округ обилује културним туристичким вредностима, чија је основна карактеристика реткост, а које су резултат уложеног људског рада. Према томе, културне вредности могу бити приказане као: археолошке вредности, објекти сакралне архитектуре, етнографске вредности, амбијенталне вредности, споменици и спомен комплекси, манифестације и винарије. Аналогно томе, следећа табела даје приказ културних вредности које могу бити валоризоване кроз различите облике туризма.

Табела 4: Културне туристичке вредности Топличког округа

\begin{tabular}{|c|c|}
\hline $\begin{array}{l}\text { Археолошке туристичке } \\
\text { вредности }\end{array}$ & $\begin{array}{l}\text { - Неолитско насеље Плочник } \\
\text { - Римске терме Баце } \\
\text { • Каптажа минералне воде из неолита Вича } \\
\text { - Средњовековно утврђење на Хисару } \\
\text { - Археолошки локалитет Кале у Бреговини } \\
\text { - Иван кула } \\
\text { - Палеонтолошки локалитет Пребреза }\end{array}$ \\
\hline $\begin{array}{l}\text { Објекти сакралне } \\
\text { архитектуре }\end{array}$ & 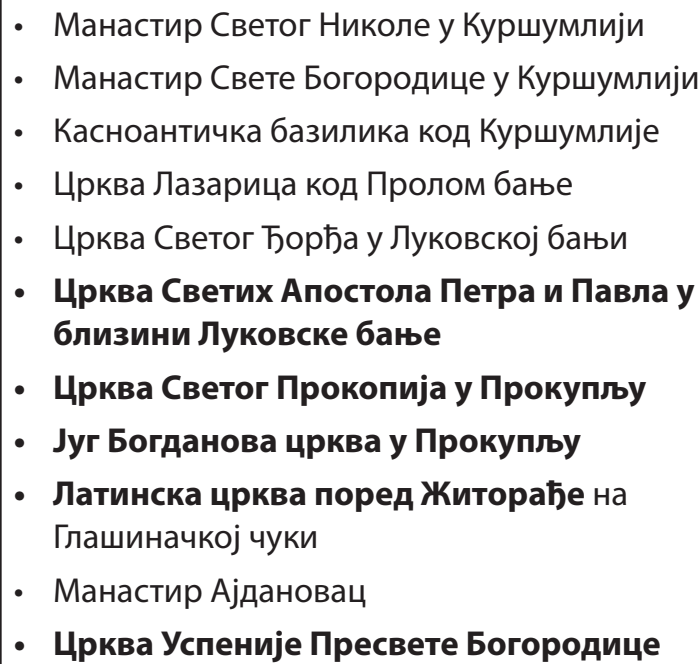 \\
\hline
\end{tabular}




\begin{tabular}{|c|c|}
\hline $\begin{array}{l}\text { Етнографске туристичке } \\
\text { вредности }\end{array}$ & $\begin{array}{l}\text { - Етно село “Бели Камен” код Прокупља } \\
\text { - Етно село „Наша авлија“ Блаце } \\
\text { • Етно кућа у Пролом бањи } \\
\text { - Сабори и вашари }\end{array}$ \\
\hline $\begin{array}{l}\text { Амбијенталне туристичке } \\
\text { вредности }\end{array}$ & $\begin{array}{l}\text { - Савићевац - задужбина др Алексе Савића у } \\
\text { Прокупљу } \\
\text { • Зграда Основне школе “Никодије Стојановић } \\
\text { Татко” } \\
\text { • Зграда Начелства у Прокупљу } \\
\text { - Зграда Народног музеја Топлице } \\
\text { - Хотел „Европа“ у Куршумлији }\end{array}$ \\
\hline $\begin{array}{l}\text { Споменици и спомен } \\
\text { комплекси }\end{array}$ & $\begin{array}{l}\text { • Споменик ослободиоцима Куршумлије у српско- } \\
\text { турском рату } \\
\text { • Споменик Топличанима палим у ратовима 1912- } \\
\text { 1918. год. и жртвама у народном устанку } 1917 . \\
\text { године у Прокупљу } \\
\text { • Костурница борцима погинулим у народној } \\
\text { револуцији у Прокупљу } \\
\text { • Спомен костурница погинулим партизанима у } \\
\text { Другом светском рату у Куршумлији }\end{array}$ \\
\hline Манифестације & $\begin{array}{l}\text { • Драинчеви сусрети } \\
\text { • Ликовна колонија Блаце } \\
\text { • Дани шљиве - Шљивијада Блаце } \\
\text { • Међународна фото-колонија Ђавоља варош } \\
\text { • Ликовна колонија “Беле Цркве” }\end{array}$ \\
\hline Винарије & $\begin{array}{l}\text { • Винарија „Доја“ Доња Јошаница код Блаца } \\
\text { • Винарија „Топлички виногради“ Гољиновац код } \\
\text { Прокупља }\end{array}$ \\
\hline
\end{tabular}

Извор: Истраживање аутора

Подаци приказани у претходној табели указују да је значајан број културних вредности лоциран на територији општине Куршумлија, а затим следи општина Прокупље. У наставку биће приказане најзначајније културне туристичке вредности Топличког округа.

Археолошка истраживања на простору Топличког округа су показала да је праисторијских насеља било у Бацу, Вичи, Плочнику и Прокупљу. Ова насеља припадају старчевачкој и винчанској културној групи. Неолитско насеље Плочник се налази у селу Плочник, 22 km југозападно од Прокупља 
а 12 km североисточно од Куршумлије. Остаци насеља се простиру са обе стране магистралног пута и железничке пруге Ниш - Приштина на површини од 120 хектара. Оно представља најзначајнији неолитски локалитет у Топличком округу. Неолитско насеље је случајно откривено 1927. године приликом изградње пруге Ниш - Прокупље - Косово и Метохија. Поред земуница и глинених кућа пронађене су и јаме за отпатке, глинено посуђе, статуе од глине, бакарне секире и длета, камене секире, оруђа од камена, кости и рогови (Народни музеј у Београду). Иако је од почетка истраживања до данас овај локалитет имао велики туристички значај, све до 2009. године није туристички валоризован, стога су га туристи само повремено обилазили. Предузеће А.Д. „Планинка“ у Куршумлији је у сарадњи са Народним музејом и општином Прокупље 2009. године изградило пет неолитских кућа, што је значајно повећало туристичку вредност овом локалитету.

За туристичку валоризацију највећи значај имају они објекти (цркве и манастири) који су рестаурирани и најбоље очувани. Они представљају праву ризницу историјских и уметничких вредности и зато се у први план ставља заштита културног наслеђа. Доба средњевековне српске државе оставило је значајне трагове материјалне и духовне културе. Међу њима, највећу туристичку вредност имају манастир Светог Николе и остаци манастира Пресвете Богородице у Куршумлији. Манастир Светог Николе је саградио Стефан Немања на узвишењу изнад ушћа реке Бањске у Топлицу. Грађена је у три фазе. Најпре је подигнута једнобродна грађевина са троделним олтарским простором и куполом. За време Стефана Првовенчаног је, уз западну страну цркве, дограђена припрата са две високе куле и засведен трем. Краљ Милутин је, у XIV веку, саградио параклис уз северну страну цркве. Црква Светог Николе представља један од најстаријих споменика средњовековне архитектуре у Србији, а служила је као прототип изградњи низа споменика рашке епохе. Црква је живописана, али су сачувани само трагови фресака из XIV века (Маћејка \& Танасковић, 2008). Манастир Пресвете Богородице је подигнут у близини ушћа Косанице у Топлицу, око $800 m$ низводно од манастира Светог Николе. Овај манастир је према мишљењу многих историчара саградио Стефан Немања непосредно пре манастира Светог Николе, између 1159. и 1165. године на темељима рановизантијске базилике из VI века и он представља усамљен пример у српској средњовековној архитектури (Споменици културе у Србији, 2005а). Стефан Немања је манастир посветио својој жени Ани, која се у њему замонашила, а неко време је у њему била и настојница (Маћејка \& Танасковић, 2008). Црква брвнара Лазарица у близини Пролом бање је једна од најзанимљивијих богомоља на подручју општине Куршумлија. Саградили су је досељеници са Голије на темељима старог храма, 
иако постоје предања да су је подигли цар Лазар уочи Косовске битке, или локално становништво након Косовског боја (Маћејка \& Танасковић, 2008). Има јединствену архитектуру која се ретко среће у градњи верских објеката на овим просторима. Саграђена је као брвнара.У основи је квадратног облика, са четвороводним кровом који је покривен црепом. Црква је добро очувана, а за њу, односно ранију богомољу, везано је неколико легенди које и данас живе у народу. Наиме, у црквеном дворишту се налази шест вишегодишњих стабала шљива, чији изглед представља праву реткост. Манастир Ајдановац се налази на $27 \mathrm{~km}$ северозападно од Прокупља, у истоименом засеоку на обронцима Јастрепца. Иако не постоји јединствено мишљење о времену његовог настанка, а узимајући у обзир архитектуру и живопис, преовлађује став да је подигнут у доба Немањића, за време владавине краља Милутина, или непосредно по турском освајању Балкана (Споменици културе у Србији, 2005 б). Налази се под заштитом Републике Србије као споменик културе од великог значаја. Захваљујући очуваним фрескама, манастир важи за најочуванији средњовековни манастир на територији Топлице, док је уједно и једини живи манастир у Топлици.

Манифестације доприносе обогаћивању садржаја боравка посетилаца и повећању дневне и укупне потрошње гостију. На подручју Топличког округа се посебно истичу Драинчеви сусрети и Дани шљиве (Шљивијада). Драинчеви сусрети је књижевно културна манифестација која се са прекидима (197075) одржава од 1966. године у Блацу и Прокупљу (Гашић, 2012). Посвећена је Радојку Јовановићу, рођеном у Трбуњу, чији је псеудоним био Раде Драинац, а који се сматра највећим српским песником и боемом између два светска рата.

У време Драинчевих сусрета обилазе се општински центри Топличког округа и родна кућа Радета Драинца. Ова манифестација окупља велики број учесника, како из Србије тако и из иностранства. Најатрактивнија и најпосећенија туристичка манифестација у Топличком округу је Шљивијада која се одржава у Блацу, сваке године крајем августа и траје четири дана. Установљена је као манифестација која је посвећена шљиви, најзначајнијем бренду општине Блаце и као таква доприноси афирмацији Блаца као недовољно развијене општине (Ловић и др., 2012). Захваљујући промени концепта, значајнију посећеност доживљава 2005. године и од тада, из године у годину, бележи све већи број посетилаца. Организатор ове, најпосећеније манифестације у овом делу Србије, су општина Блаце и Туристичка организација Блаце (Општина Блаце, www.blace.org.rs). Манифестација се одвија у више праваца: привредном, туристичком, забавном и културном. 
За туризам, виногради представљају важну компоненту атрактивности и могу бити један од мотивационих фактора за туристе (Пивац и др., 2009). Од 2007. године Топличани почињу да обнављају винограде и 2011. године отворене су винарије „Доја“ и „Топлички виногради“, те се стварају услови за развој винског туризма, као посебног облика културног туризма.

\section{ЗАКЉУЧАК}

Прогнозе Светске туристичке организације говоре да ће се број туриста повећавати, односно да ће 2030. године у међународним туристичким кретањима учествовати 1,8 милијарди туриста и да би потрошња тада износила преко 2 билиона USD (UNWTO, 2017). Процењује се да културни туризам учествује са око 39\% у међународним туристичким кретањима, као и да се културни туризам убраја у пет водећих сегмената туристичког тржишта (Richards, 2018).

Понуда српских туристичких производа, која се спонтано развијала за потребе домаћег туризма, данас није у стању да одговори савременим захтевима међународног туристичког тржишта, јер су се на том тржишту догодиле велике промене према којима Република Србија није прилагодила своју туристичку понуду (Perić i dr., 2018). Културни туризам у Републици Србији се још увек не издваја као јасно профилисан вид туризма, јер културне вредности нису претворене у осмишљене туристичке прозиводе и још увек чине само потенцијале на којима може да се развија културни туризам. 36ог тога је потребно културне вредности инкорпорирати у већ профилисане туристичке производе, у складу са захтевима савременог туристе.

Топлички округ поседује многобројне природне и културне вредности које нису на прави начин туристички валоризоване. Најразвијенији је бањски туризам, и то на подручју општине Куршумлија. На територији Топличког округа постоје бројни археолошки локалитети које би требало укључити у туристичку понуду, и то: неолитско насеље Плочник, Римске терме, Бреговина, Злата, Велико Кале и Ргаје. Ови локалитети нису у потпуности истражени, али би свакако обогатили садржај туристичке понуде. Културно-историјски споменици, као што су прве задужбине Немањића, манастири Св. Николе и Св. Богородице, манастир Ајдановац, Латинска црква и Лазарица, такође могу бити занимљиви као допунски туристички садржаји већ профилисаног бањског туризма, или у оквиру туристичке понуде верског туризма. Када говоримо о манифестацијама, посебно се истичу Драинчеви сусрети и 
Дани шљиве (Шљивијада). Шљивијада је најатрактивнија и најпосећенија туристичка манифестација у Топличком округу која се одржава сваке године крајем августа у Блацу. Највећи проблем представља недостатак смештајних капацитета током одржавања манифестације.

Приватизацијом већине постојећих угоститељских капацитета, обновљени су само ресторатерски капацитети који су захтевали мања улагања, док су изостала улагања у смештајне капацитете. Овом правилу пркоси хотел „Hammeum“ у Прокупљу. Значајну улогу у модернизацији постојећих, али и развоју и изградњи нових туристичких и смештајних капацитета целог Топличког округа има А.Д. “Планинка” из Куршумлије. Једино општина Куршумлија задовољава туристичку потражњу у погледу смештајних капацитета, и то претежно у Пролом и Луковској Бањи. У осталим општинама округа готово да нема туристичког промета, или нема регистрације туриста у приватном смештају, о чему сведоче подаци Републичког завода за статистику. Осмишљеним маркетинг методама може се повећати туристички промет, пре свега у бањама. Туристички промет је највећи током летње туристичке сезоне. Обогаћивањем туристичке понуде културним садржајима може се повећати број туриста током целе године.

Нови туристички трендови, који инсистирају на очувању природних и културних туристичких вредности, захтевају и преиспитивање основних развојних праваца туризма у Топличком округу. Другим речима, будући туристички развој мора бити сагласан са концептом одрживог развоја. Израда појединачних стратегија туристичког развоја за сваку општину у округу, или једне заједничке на нивоу Топличког округа, представља полазну тачку планског развоја туризма. Данас су уређење туристичког простора, опремање туристичких локалитета, изградња инфраструктуре и туристичко планирање, најчешће препуштени нестручним лицима, која нису у могућности да сагледају правце развоја туризма. За развој туризма у Топличком округу, неопходно је планско и тржишно позиционирање општина на различитим нивоима. Развојна стратегија туризма у дестинацији мора да буде јасно дефинисана и сагласна са расположивим туристичким вредностима и туристичком инфраструктуром. С обзиром на стање материјалне базе за развој туризма у Топличком округу у наредном периоду неопходни су даље унапређење и развој саобраћајне, туристичке, комуналне и остале инфраструктуре.

Као што је већ наведено, Топлички округ поседује бројне културне туристичке вредности које нису валоризоване на адекватан начин и још увек чине само потенцијале на којима може да се развија културни туризам, али не као засебан вид туризма, већ првенствено као обогаћивање већ профилисаног бањског туризма. 


\section{ЛИТЕРАТУРА}

1. Bakić, O. (2005). Marketing menadžment turističke destinacije. Čigoja štampa.

2. Бојовић, Г. (2012). Копаоник и бање у подгорини. Српско географско друштво.

3. Vrtiprah, V. (2006). Kulturni resursi kao činitelj turističke ponude u 21. stoljeću. Ekonomska misao i praksa, (2), 279-296.

4. Гашић, М. (2012). Економско-географска валоризачија туристичких потенцијала Топличког округа. Мастер рад. Економски факултет Универзитета у Нишу

5. Гашић, М., \& Ивановић, В. (2015). Туристичко - географски положај Топличког округа. БизИнфо (Блаце), 6(1), 53-64. https://doi.org/10.5937/BIZINFO1501053G

6. Gašić, M., Ivanović, V. \& Perić, G. (2015). Materijalna baza razvoja turizma na prostoru Topličkog okruga. U: Synthesis 2015 - International Scientific Conference of IT and Business - Related Research. (str. 494-498). Univerzitet Singidunum. https://doi. org/10.15308/Synthesis-2015-494-498

7. Đukić Dojčinović, V. (2005). Kulturni turizam: menadžment i razvojne strategije. Clio.

8. Jevtović, A. (2020). „Contribution of Slovenian Architect Franc Avbelj and "Planinka” Company to the Development of Tourism in Serbia: A Case Study of the Urban-Architectural Solution of Kuršumlija Spa", Histories of Postwar Architecture, Depts. Of Architecture, The Arts and for Life Quality Studies - University of Bologna, in print.

9. Jovanović-Tončev, M., \& Podovac, M. (2014). Kulturna dobra kao deo turističkog proizvoda banja Srbije. Ekonomija: teorija i praksa, 7(3), 54-67. https://doi.org/10.5937/ etp1403054J

10. Jovanović, V. (2015). Tematski turizam.Univerzitet Singidunum.

11. Ловић, С., Бјељац, Ж., \& Цветковић, М. (2012). Туристичка манифестација „Дани шљиве-шљиво моја" у Блацу - анализа географског порекла посетилаца и њихових одређених демографских карактеристика. Зборник радова Географског института Јован Цвијић, 62(2), 83-95.

12. Маћејка, М. \& Танасковић, Р. (2008). Општина Куршумлија - Туристичка монографија и водич. ПУНТА и ТО Куршумлија.

13. Милошевић, С. (2014). Чиниоци развоја културног туризма - студија случаја Бар, Црна Гора. Пословна економија, 8(1), 259-280. https://doi.org/10.5937/ PosEko1401259M

14. Народни музеј. (нема података). Плочник. Приступљено 22.08.2020. http://www. narodnimuzej.rs/za-strucnjake/projekti-narodnog-muzeja/arheoloski-projekti/aktuelna-arheoloska-istrazivanja/plocnik/ 
15. Petković, S. (2019). Menadžment kulturnih resursa u turizmu. Univerzitet Singidunum.

16. Perić, G., Avramović, M. \& Stojiljković, M. (2018). Achieved level of tourism development in the Republic of Serbia. Bizinfo (Blace), 9(2), 39-52. https://doi.org/10.5937/ bizinfo1802039P

17. Пивац, Т., Ромелић, Ј., \& Кошић, К. (2009). Оцена потенцијала за развој винског туризма у Војводини. Зборник радова - Географски факултет Универзитета у Београду, (57), 215-228.

18. Ракић, С., Мухи, Б., \& Томка, Д. (2014). Утицај светске економске кризе на глобални туристички промет са посебним освртом на Републику Србију. Пословна економија, 8(1), 281-306.https://doi.org/10.5937/PosEko1401281R

19. Richards, G. (2018). Cultural tourism: A review of recent research and trends. Journal of Hospitality and Tourism Management, 36, 12-21. https://doi.org/10.1016/j. jhtm.2018.03.005

20. Радио Телевизија Србије. (2020, 24 април). Обнова Куршумлијске бање, први гости наредне године. https://www.rts.rs/page/stories/ci/story/56/srbija-danas/3936137/ obnova-kursumlijske-banje.html

21. Републички завод за статистику. (2020). Доласии и ноћења туриста по регионима и областима - годишњи подачи. https://data.stat.gov.rs/Home/ Result/220201 ?languageCode=sr-Cyrl\&displayMode=table\&guid=487f1 dad-01094236-8f69-1f08383c09b6

22. Sančanin, B., Perić, G., \& Stojiljković, M. (2019). Cultural-historical resources as initiators of tourism development in Sremski Karlovci. Menadžment u hotelijerstvu i turizmu, 7(2), 77-85.https://doi.org/10.5937/menhottur1902077S

23. Sančanin, B. (2019). Historical heritage in the function of developing cultural tourism. Journal of Middle East and North Africa Sciences, 5(5), 6-12.

24. Споменици културе у Србији. (2005а). Манастир Пресвете Богородиче у Куршумлијu. http://spomenicikulture.mi.sanu.ac.rs/spomenik.php?id=553

25. Споменици културе у Србији. (20056). Манастир Св. Ђорђа у Ајдановиу. http://spomenicikulture.mi.sanu.ac.rs/spomenik.php?id=460\#

26. Turistički svet. (2017, 25 decembar). Lukovska banja dobija novi hotel sa 4 zvezdice - početak izgradnje na proleće. https://www.turistickisvet.com/vesti/hotelijerstvo/ lukovska-banja-dobija-novi-hotel-sa-4-zvezdice---pocetak-izgradnje-na-prolece.html

27. Csapo, J. (2012). The role and importance of cultural tourism in modern tourism industry. In Strategies for tourism industry-micro and macro perspectives.(pp. 201-232). InTech. https://doi.org/10.5772/38693

28. Čerović, S., Barjaktarović, D., \& Knežević, M., (2015). Podrška razvoju turizma kao faktor konkurentnosti Srbije kao turističke destinacije. U: SITCON 2015 - Singidunum Interna- 
tional Tourism Conference. (str. 1-8). Singidunum Univerzitet. https://doi.org/10.15308/ sitcon-2015-1-8

29. Hrbovski - Tomić, E. (2008). Selektivni oblici turizma. Fakultet za uslužni biznis.

30. World Tourism Organization. (2017). UNWTOTourismHighlights: 2017 Edition. https:// doi.org/10.18111/9789284419029

Рад је примљен: 26. август 2020. Прихваћен за објављивање: 31. август 2020.

Received: August 26, $2020 . \quad$ Accepted: August 31, 2020. 